\title{
Milk protein composition and stability changes affected by iron in water sources
}

\author{
Aili Wang, ${ }^{*}$ Susan E. Duncan, ${ }^{* 1}$ Katharine F. Knowlton, † William K. Ray, $\ddagger$ and Andrea M. Dietrich§ \\ *Department of Food Science and Technology, \\ †Department of Dairy Science, \\ ‡Department of Biochemistry, and \\ §Department of Civil and Environmental Engineering, Virginia Tech, Blacksburg 24061
}

\begin{abstract}
Water makes up more than $80 \%$ of the total weight of milk. However, the influence of water chemistry on the milk proteome has not been extensively studied. The objective was to evaluate interaction of water-sourced iron (low, medium, and high levels) on milk proteome and implications on milk oxidative state and mineral content. Protein composition, oxidative stability, and mineral composition of milk were investigated under conditions of iron ingestion through bovine drinking water (infused) as well as direct iron addition to commercial milk in 2 studies. Four ruminally cannulated cows each received aqueous infusions (based on water consumption of $100 \mathrm{~L}$ ) of $0,2,5$, and $12.5 \mathrm{mg} / \mathrm{L} \mathrm{Fe}^{2+}$ as ferrous lactate, resulting in doses of $0,200,500$ or $1,250 \mathrm{mg}$ of $\mathrm{Fe} / \mathrm{d}$, in a $4 \times 4$ Latin square design for a 14-d period. For comparison, ferrous sulfate solution was directly added into commercial retail milk at the same concentrations: control (0 mg of Fe/L), low (2 mg of $\mathrm{Fe} / \mathrm{L}$ ), medium ( $5 \mathrm{mg}$ of $\mathrm{Fe} / \mathrm{L}$ ), and high (12.5 $\mathrm{mg}$ of $\mathrm{Fe} / \mathrm{L}$ ). Two-dimensional electrophoresis coupled with matrix-assisted laser desorption/ionization-tandem time-of-flight (MALDI-TOF/TOF) high-resolution tandem mass spectrometry analysis was applied to characterize milk protein composition. Oxidative stability of milk was evaluated by the thiobarbituric acid reactive substances (TBARS) assay for malondialdehyde, and mineral content was measured by inductively coupled plasma mass spectrometry. For milk from both abomasal infusion of ferrous lactate and direct addition of ferrous sulfate, an iron concentration as low as 2 mg of $\mathrm{Fe} / \mathrm{L}$ was able to cause oxidative stress in dairy cattle and infused milk, respectively. Abomasal infusion affected both caseins and whey proteins in the milk, whereas direct addition mainly influenced caseins. Although abomasal iron infusion did not significantly af-
\end{abstract}

Received October 2, 2015.

Accepted February 26, 2016.

${ }^{1}$ Corresponding author: duncans@vt.edu fect oxidation state and mineral balance (except iron), it induced oxidized off-flavor and partial degradation of whey proteins. Direct iron addition to milk led to lipid oxidation during storage at $4^{\circ} \mathrm{C}$. Oxidation level was positively associated with the concentration of added iron. Minerals (Mg, P, Na, K, Ca, Zn) in milk were not affected by the added iron in milk. This study indicated that a small amount of iron contamination in bovine drinking water at the farm or incidental iron addition from potable water sources causes oxidation, affects milk protein composition and stability, and affects final milk quality.

Key words: iron, protein, oxidation, milk synthesis

\section{INTRODUCTION}

Cow milk and related dairy products are nutritious foods containing numerous essential nutrients, especially milk proteins, which serve as an excellent source for essential amino acids. Milk proteins are composed of caseins (80\%) and whey proteins (20\%). Caseins are known to carry calcium and phosphate, which have many bioactive functions and contribute to efficient digestion (Haug et al., 2007). Whey proteins possess a variety of nutritional and biological properties and thus are widely used in reducing the risk of diseases such as cancer (de Wit, 1998; Gill and Cross, 2000), inflammation (Clare et al., 2003), chronic stress-induced disease (Ganjam et al., 1997), and human immunodeficiency virus infection (Oona et al., 1997; Micke et al., 2002). Bovine whey proteins perform their biological functions through constituents including $\beta-\mathrm{LG}$ (mediate and transport immunoglobulins during colostrum formation), $\alpha$-LA (lactose synthase component and possible antimicrobial and anticancer activity), immunoglobulins (serving as antibodies to protect the mammary gland from infection), serum albumin (antimutagenic, anticancer, and immunomodulation activity), lactoferrin (iron-binding, iron transport, antimicrobial, antiinflammatory, and anticancer activities, immune system modulation), and lactoperoxidase (antimicrobial and 
antioxidant properties) (Swaisgood, 1995; Levieux and Ollier, 1999; Loimaranta et al., 1999; Haug et al., 2007; Adlerova et al., 2008; Alonso-Fauste et al., 2012).

Quality and yield of bovine milk proteins are determined by genetics of dairy cows, hormones, dietary energy, and lactation environment (Bionaz et al., 2012). Recently, excess iron ingestion was found to affect cow health through the formation of an oxidation environment and to interfere with absorption of other minerals (Hansen et al., 2010); this may contribute to increases in mastitis, bacterial infection, and retained fetal membranes, and a decrease in immunity (Standish et al., 1971; Bullen et al., 1978; Linn, 2008). A decline in the health status of dairy cattle immediately depresses their milk production and alters milk composition, including loss of milk yield (Gröhn et al., 2004), decrease in lactose and fat contents (Bansal et al., 2005), and increases in sodium, chloride, and electrical conductivity (Bruckmaier et al., 2004). However, effect of ironinduced oxidative stress on milk protein synthesis of lactating dairy cows has not been studied yet.

Dairy cattle drink 90 to $150 \mathrm{~L}$ of water each day when producing milk (Feng et al., 2013). A common resource for bovine drinking water is groundwater, where water can dissolve iron and other minerals as it percolates through soil and rock and hold the minerals in solution. The US Environmental Protection Agency (USEPA) reported that $\mathrm{Fe}$ concentration in ground water of many regions in the United States exceeds the secondary maximum contaminant levels $(0.3 \mathrm{mg}$ of $\mathrm{Fe} / \mathrm{L}$ ) set by that agency (USEPA, 2015). Due to the large amount of water consumed by dairy cows per day, ferrous Fe in milligrams-per-liter concentrations makes water a potentially significant source of iron intake for cows. In addition, although direct addition of water during fluid milk processing is not legal, incidental contamination may occur related to the use of potable water when cleaning equipment on the farm or in the processing plant. In addition, potable water is used as an ingredient in the manufacture of many dairy-based products, providing an avenue for the incidental addition of iron and contact with milk proteins. However, there is limited information about the effects of iron ingestion either in vivo or in vitro on quality of milk proteins.

This study is part of a larger interdisciplinary study involving the implications of water-sourced iron on milk quality. Feng et al. (2013) described the experimental conditions of the in vivo study on phosphorus absorption in lactating dairy cows. Concurrently, Mann et al. (2013) evaluated the subsequent effect of milk synthesized under the experimental conditions on fluid milk sensory quality. Our objective in this study was to evaluate the interaction of water-sourced iron (low, medium, and high levels), as determined through in vivo (water provided to dairy cattle) and in vitro (direct addition to whole processed milk) delivery, on the milk proteome and implications for other milk quality parameters, including oxidative state and mineral content. Our null hypothesis was that no differences in milk proteome, oxidative status, or mineral content would be observed using either the in vivo or the in vitro approach. Our alternative hypothesis was that both ways of iron ingestion would affect the milk proteome, affect milk mineral content, and contribute to changes in oxidative stability. Milk used for the in vivo portion of this study was sourced from this interdisciplinary study.

\section{MATERIALS AND METHODS}

\section{Milk Samples Collected from Individual Farm Cows}

Experiment Design and Raw Milk Collection. Protocols and procedures of this experiment were approved by the Virginia Tech Institutional Animal Care and Use Committee (12-027-DASC). Details of the in vivo experimental study are reported in Feng et al. (2013). In brief, 4 ruminally cannulated early lactation (second-lactation) cows $(2$ Holstein and 2 Holstein $x$ Jersey cross) were isolated from external water sources to eliminate outside variables, housed in individual stalls, and placed on a standard basal diet and water source (Feng et al., 2013). Abomasal infusion of ferrous lactate was performed as described in our previous work (Feng et al., 2013). Treatments (abomasal infusion of $0,200,500$, or $1,250 \mathrm{mg}$ of $\mathrm{Fe} / \mathrm{d}$ as ferrous lactate solution) were imposed in a $4 \times 4$ Latin square design with 14-d periods. Treatments were formulated to approximate $0,2,5$, or $12.5 \mathrm{mg}$ of $\mathrm{Fe} / \mathrm{L}$ concentrations in drinking water, assuming water intake of 100 $\mathrm{L} / \mathrm{d}$. The infusion treatment design is summarized in Tables 1 and 2. Milk samples were collected from the evening milking of each cow at d 13 of each period, allowing for $6 \mathrm{~d}$ of total infusion time before milk collection, as described by Feng et al. (2013).

Milk Processing. Details of the milk processing are described in full in Mann et al. (2013). In brief, raw milk was collected in 5-gallon stainless steel milk cans and immediately transported to the Food Science and Technology Dairy Processing Laboratory, and stored in a cooler (Tonka, Hopkins, MN) at $4^{\circ} \mathrm{C}$. Milk from each period for each cow was processed separately. After preheating to 55 to $60^{\circ} \mathrm{C}$, milk was separated into cream and skim milk using a pilot-plant separator (Elecrem separator, model IG, 6400rpm, Bonanza Industries Inc., Calgary, AB, Canada). Cream was then added back to skim milk to achieve $3.18 \pm 0.04 \%$ milk 
Table 1. Concentration of ferrous lactate infused in bovine drinking water and expected ingestion by cow, and concentration of ferrous sulfate added to commercial whole milk

\begin{tabular}{lcccc}
\hline & \multicolumn{2}{c}{ Cow diet } & & \\
\cline { 2 - 4 } Treatment & $\begin{array}{c}\text { Infusion concentration } \\
(\mathrm{mg} \text { of Fe/L) }\end{array}$ & $\begin{array}{c}\text { Infused ferrous dose } \\
(\mathrm{mg} \text { of Fe/d) }\end{array}$ & $\begin{array}{c}\text { Equivalent drinking water concentration } \\
(\mathrm{mg} \text { of Fe/L of water })\end{array}$ & $\begin{array}{c}\text { Commercial whole milk } \\
(\mathrm{mg} \text { of Fe/L of milk) }\end{array}$ \\
\hline Control & 0 & 0 & 0 & 0 \\
Low & 200 & 200 & 5 & 2 \\
Medium & 500 & 500 & 12.5 & 5 \\
High & 1,250 & 1,250 & & 12.5 \\
\hline
\end{tabular}

${ }^{1}$ Assumes cow ingests $100 \mathrm{~L}$ of water per day (Feng et al., 2013).

fat. The homogenization of milk was conducted using a laboratory 2-stage homogenizer $[13.8 \mathrm{MPa}(2,000$ psi) - first stage; $5.52 \mathrm{MPa}$ (800 psi) - second stage] (model 15MR, 55.2 MPa (8,000 psi); APV Gaulin Inc., Everett, MA). Standardized milk was vat pasteurized at $66^{\circ} \mathrm{C}$ for $30 \mathrm{~min}$ and microbial quality was assessed by aerobic plate count standard methods using aerobic count Petrifilm (3M Petrifilm, Microbiology Products 3M Health Care, St. Paul, MN). Processed milk was packaged in translucent food-grade high-density polyethylene gallon packages, which were presanitized with a chlorine $(100 \mathrm{mg} / \mathrm{kg}$ ) rinse (distilled water; Mann et al., 2013). Samples of the processed milk were then immediately frozen at $-80^{\circ} \mathrm{C}$ for subsequent analyses.

\section{Milk Samples Collected from Commercial Retail Milk}

Milk (3.25\% milk fat, HTST pasteurized, Kroger, Cincinnati, $\mathrm{OH}$ ) was purchased from the local supermarket in 1.89-L packages. Milk samples were collected from the top, middle, and bottom layer of the bottle as 3 replicates used for each iron treatment. Stock ferrous sulfate solution (200 $\mathrm{mg}$ of $\mathrm{Fe} / \mathrm{L}$ of water) was prepared by adding $0.25 \mathrm{~g}$ of food-grade ferrous sulfate $\left(\mathrm{FeSO}_{4} \cdot 7 \mathrm{H}_{2} \mathrm{O}\right.$, Spectrum, Gardena, CA) into $250 \mathrm{~mL}$ of double-distilled water. To compare with the iron treatments used the in vivo study, the same 4 ferrous concentrations were used in commercial retail milk with direct addition of ferrous sulfate. The concentra- tions were achieved by adding stock ferrous solution to each $10 \mathrm{~mL}$ of milk: $0 \mathrm{~mL}$ in $30 \mathrm{~mL}$ of milk for control treatment ( $0 \mathrm{mg}$ of $\mathrm{Fe} / \mathrm{L}$ of milk), $0.1 \mathrm{~mL}$ in $29.9 \mathrm{~mL}$ of milk for the low treatment (2 mg of Fe/L of milk), $0.25 \mathrm{~mL}$ in $29.75 \mathrm{~mL}$ of milk for the medium treatment (5 mg Fe/L of milk), and $0.62 \mathrm{~mL}$ in $29.38 \mathrm{~mL}$ milk for the high treatment (12.5 mg Fe/L of milk). Milk samples were immediately covered with aluminum foil to protect from light and stored at $4^{\circ} \mathrm{C}$. Before protein analysis, milk samples were centrifuged at 16,000 $\times \mathrm{g}$ for $15 \mathrm{~min}$ at $4^{\circ} \mathrm{C}$ and the upper fat layer was discarded. Three replications were completed for this study, following a complete block design.

\section{Protein Analysis by Two-Dimensional Gel Electrophoresis}

Chemicals. Urea, Trizma base, glycerol, iodoacetamide, CHAPS (detergent), protease inhibitor cocktail, and SDS were purchased from Sigma-Aldrich (St. Louis, MO), 2-D clean-up kit, 2-D quant kit, Immobiline dry strip $\mathrm{pH} 4-7(11 \mathrm{~cm})$, and immobilized $\mathrm{pH}$ gradient (IPG) buffer ( $\mathrm{pH} 4-7$ ) were purchased from GE Healthcare Life Sciences (Pittsburgh, PA). Criterion Tris-HCl gels (10-20\%) were purchased from Bio-Rad (Hercules, CA).

Protein Preparation. Frozen $\left(-80^{\circ} \mathrm{C}\right)$ processed milk samples were thawed on ice for about $2 \mathrm{~h}$ before use and then mixed thoroughly by vortex mixer.

Table 2. Latin square design (Feng et al., 2013) for in vivo study showing iron intake ${ }^{1}$ by abomasal infusion for each cow in each period ${ }^{2}$

\begin{tabular}{lllll}
\hline Cow number $^{3}$ & Period 1 & Period 2 & Period 3 & Period 4 \\
\hline 4541 & Control & Low & Medium & High \\
4543 & Low & High & Control & Medium \\
4558 & Medium & Control & High & Low \\
4559 & High & Medium & Low & Control \\
\hline
\end{tabular}

${ }^{1}$ Four treatments of iron intake were $0,2,5$, and $12.5 \mathrm{mg}$ of $\mathrm{Fe} / \mathrm{L}$ for control, low, medium, and high treatments, respectively.

${ }^{2}$ Period of infusion: daily infusion of $1 \mathrm{~L}$ of ferrous lactate solution with assigned iron concentration for $7 \mathrm{~d}$; there was a wash out period of $7 \mathrm{~d}$ before each infusion period.

${ }^{3}$ Jersey $\times$ Holstein [4541 (cow A), 4543 (cow B)]; Holstein [4558 (cow C), 4559 (cow D)]. 
Thawed samples were further centrifuged at 16,000 $\times g$ for $15 \mathrm{~min}$ at $4^{\circ} \mathrm{C}$. The upper fat layer, which contained cell debris (somatic cells and bacteria) and most of the casein, was then discarded (Alonso-Fauste et al., 2012).

Proteins from skim milk were extracted using the 2-D clean-up kit following the kit's instructions. Extracted protein pellet was dissolved in rehydration buffer, containing $8 M$ urea, $2 M$ thiourea, $2 \%$ CHAPS (wt/vol), $1.8 \mathrm{~m} M$ dithiothreitol (DTT), and 1\% (vol/vol) IPG buffer, and $0.01 \%$ bromophenol blue (Alonso-Fauste et al., 2012). Protein concentration was determined by using the 2D quant kit following the protocol given in the brochure and using BSA as a standard.

Two-Dimensional Electrophoresis. Precast 11cm strips, pH range 4-7 (GE Healthcare) were rehydrated in the presence of $200 \mu \mathrm{g}$ of milk protein at $20^{\circ} \mathrm{C}$ for $12 \mathrm{~h}$. Isoelectric focusing was carried out using an Ettan IPGphor 3 Cell (GE Healthcare) for $10 \mathrm{kVh}$ using the following voltage program: (1) from 0 to 200 $\mathrm{V}$ over $0.5 \mathrm{~h}$; (2) from 200 to $500 \mathrm{~V}$ over $0.5 \mathrm{~h}$; (3) from 500 to $1,000 \mathrm{~V}$ over $1 \mathrm{~h}$; (4) from 1,000 to 8,000 V over $1 \mathrm{~h}$; (5) held at 8,000 V for $5 \mathrm{~h}$ (Yamada et al.., 2002). The IPG strips were incubated in the first equilibration buffer [1\% DTT (wt/vol), $375 \mathrm{mM}$ Tris-HCl (pH 8.8), $6 M$ urea, $20 \%$ glycerol (vol/vol), $2 \%$ SDS (wt/ vol), $0.01 \%$ bromophenol blue (wt/vol)] for $20 \mathrm{~min}$, and followed by the second equilibrium buffer $[2.5 \%$ iodoacetamide (wt/vol), $375 \mathrm{mM}$ Tris- $\mathrm{HCl}(\mathrm{pH} 8.8), 6$ $M$ urea, $20 \%$ glycerol (vol/vol), $2 \%$ SDS (wt/vol), and $0.01 \%$ bromophenol blue (wt/vol)] for another $20 \mathrm{~min}$ (Alonso-Fauste et al., 2012). Strips were then transferred onto 10 to $20 \%$ gradient Criterion Tris- $\mathrm{HCl}$ polyacrylamide gels and coated with $0.5 \%$ low-melt agarose (wt/vol) containing $0.01 \%$ bromophenol blue (wt/vol). The SDS-PAGE was carried out using a charged cell (Bio-Rad) for $15 \mathrm{~min}$ at $35 \mathrm{~mA}$ and then for $1.5 \mathrm{~h}$ at 70 $\mathrm{mA}$. Gels were stained by Coomassie blue for $21 \mathrm{~h}$ and then destained for $4 \mathrm{~h}$.

In-Gel Trypsin Digestion and MS Identification. Protein identification was conducted by matrixassisted laser desorption/ionization time-of-flight (MALDI-TOF) and tandem time-of-flight (TOF/ TOF) high-resolution tandem MS analysis, which was slightly modified according to the method of Chevalier et al. (2006). Protein spots were excised from 2-dimensional electrophoresis (2-DE) gels by hand with a spot picker. The cut pieces were transferred into a clean 0.6-mL tube and destained using a mixture of $25 \mathrm{mM}$ ammonium bicarbonate and HPLC-grade acetonitrile (1:1, vol/vol) for about $2 \mathrm{~h}$ with constant shaking at room temperature. After carefully removing the liquid in the tube, the gel pieces were washed again with the above mixture. Then, $25 \mathrm{~m} M$ HPLC-grade acetonitrile was added to the gel pieces and incubated for $15 \mathrm{~min}$ with constant shaking at room temperature. Gel pieces then were thoroughly dried by vacuum concentrator (Labconco Corporation, Kansas City, MO). Protein digestion was carried out by addition of $0.065 \mu \mathrm{g}$ of trypsin, followed by incubation on ice for $15 \mathrm{~min}$, and then on a heat block at $37^{\circ} \mathrm{C}$ overnight.

For mass spectra analysis, $1 \mu \mathrm{L}$ of each digest was transferred to a freshly polished MALDI plate and covered with freshly prepared matrix containing $4 \mathrm{mg} / \mathrm{mL}$ Q-cyano-4-hydroxycinnamic acid, $50 \% \quad \mathrm{CH}_{3} \mathrm{CN}, 0.1 \%$ trifluoroacetic acid (vol/vol), $0.1 \%$ formic acid (vol/ vol), and $5 \mathrm{mM}\left(\mathrm{NH}_{4}\right) \mathrm{Cl}$. Data collection was performed by using an Applied Biosystems 4800 MALDI-TOF/ TOF mass spectrometer (AB Sciex, Framingham, MA). The MASCOT search engine software (Matrix Science, Boston, MA) was used to search the NCBInr database (http://www.matrixscience.com/cgi/search_form.

pl?FORMVER=2\&SEARCH=MIS)). The parameters for searching and identifying matches were adjusted as follows: mass tolerance of $30 \mathrm{ppm}$, a minimum of 5 peptides matching to the protein, carbamidomethylation of cysteine as fixed modification oxidation of methionine as variable modifications, and one missed cleavage allowed. The MASCOT parameters were regulated as follows: parent ion mass tolerance of $20 \mathrm{ppm}$ and fragment ion mass tolerance of $100 \mathrm{ppm}$.

\section{Oxidative Stability}

Thiobarbituric acid reactive substance (TBARS) was used as an indicator of oxidative stress in milk and was calculated as malondialdehyde (MDA) value in sample (Mann et al., 2013). To test the oxidative stress of milk caused by addition of iron, TBARS of commercial milk samples was detected on d 1 after adding ferrous sulfate and on d 8 after storing in a cooler at $4^{\circ} \mathrm{C}$. For TBARS analysis, each milk sample was diluted with deionized water at a 1:2 ratio. Then, 1 $\mathrm{mL}$ of diluted milk sample and MDA standard $(0,0.18$, 0.36 , and $0.54 \mathrm{mg} / \mathrm{L}$ ) were mixed with $2 \mathrm{~mL}$ of solution I ( $0.375 \%$ thiobarbituric acid, $0.506 \%$ SDS, $9.370 \%$ acetic acid) and $0.1 \mathrm{~mL}$ of solution III (antioxidant and chelator solution). After digestion for $60 \mathrm{~min}$ at $95^{\circ} \mathrm{C}$ in a water bath, the milk samples were immediately cooled in an ice bath, followed by mixing with $2 \mathrm{~mL}$ of pyridine: $n$-butanol mixture (1:15) and centrifuged for $15 \mathrm{~min}$ at $3,000 \times \mathrm{g}$. The absorbance of the supernatant was measured with a spectrophotometer (Milton Roy Spectronic 21D Spectrophotometer, Milton Roy Co., Rochester, NY) at $532 \mathrm{~nm}$. The concentration of MDA of each milk sample was calculated based on a standard curve made by means of a linear regression on absorbance values and concentration of MDA standard (Mann et al., 2013). 


\section{Mineral Analysis}

Sodium, magnesium, calcium, potassium, copper, iron, zinc, and inorganic phosphorus concentrations of each milk sample were measured by emission spectroscopy using the inductively coupled plasma (ICP) technique (X-Series ICP-MS, Thermo Electric Corp., Waltham, MA; Menegário et al., 2001). Frozen milk samples $\left(-80^{\circ} \mathrm{C}\right)$ were thawed on ice for about $2 \mathrm{~h}$. Thawed samples were centrifuged at $18,500 \times g$ for 15 min to reduce viscosity and remove debris. Sample digestion was modified from the previous studies (Menegário et al., 2001; Watanabe et al., 2005) by diluting each milk sample at 1:10 (vol/vol) with $4 \%$ nitric acid. Iron standard (1 mg of $\mathrm{Fe} / \mathrm{L})$ was prepared by mixing $4.75 \mathrm{~mL}$ of $\mathrm{FeSO}_{4} \cdot 7 \mathrm{H}_{2} \mathrm{O}$ with $250 \mu \mathrm{L}$ of nitric acid, and reagent blank was prepared by adding $250 \mu \mathrm{L}$ of nitric acid to $4.75 \mathrm{~mL}$ of nanopure water.

\section{Data Analysis}

Milk from individual cows while in the control treatment served as the baseline control for each treatment condition in the in vivo study. Milk from the commercial milk source, without the direct addition of iron, served as the baseline control for the in vitro study. Changes in milk protein composition were analyzed by PDQuest software v.7.3.1 (Bio-Rad). Protein spots that had a least a 2-fold change in intensity were considered different among treatments in each replicated group. Protein concentration (intensity) was determined as the percentage of total valid spots' volume on respective gels. $P$-values were calculated based on Wilcoxon test, and $P$ $<0.05$ was used as cutoff for significance. Differences in milk minerals and oxidation levels between iron treat- ments (in vivo abomasal infusion of ferrous lactate or in vitro direct addition of ferrous sulfate) were analyzed by one-way ANOVA. One-way ANOVA was performed using the statistical software program JMP 10.0 (SAS Institute Inc., Cary, NC). For all analyses, $P$-values $<$ 0.05 were considered statistically significant.

\section{RESULTS AND DISCUSSION}

\section{Effect of Abomasal Infusion of Ferrous Lactate on Milk Protein Synthesis of Individual Farm Cows}

Total protein concentration in the milk of individual farm cows abomasally infused with ferrous lactate was $3.37 \pm 0.16 \%$ (Feng et al., 2013), which was within the normal range (2.97-3.74\%) reported by Lundén et al. (1997). After in-gel image analysis, 69 protein spots with expression changes ( $\geq 1.1$-fold) in spot intensity were detected in the milk of individual farm cows with increasing abomasally infused ferrous lactate. These milk protein spots were further excised, in-gel tryptic digested, and analyzed by MALDI-TOF-TOF MS. Identified protein spots are listed in Table 3 and marked on each 2-DE image with consistent spot ID numbers.

Identified milk protein spots in this study contained all classes of casein $\left(\alpha_{\mathrm{S1}^{-}}, \alpha_{\mathrm{S2}^{-}}, \beta-\right.$, and $\left.\kappa_{-} \mathrm{CN}\right)$ and whey proteins ( $\beta-\mathrm{LG}, \alpha-\mathrm{LA}$, serum albumin, immunoglobulins, lactoferrin, and lactoperoxidase), which is in agreement with previous studies (Chevalier et al., 2009; Senda et al., 2011; Alonso-Fauste et al., 2012; Jensen et al., 2012). The position of these protein spots also roughly corresponded to the reported milk protein proteome (Chevalier et al., 2009; Jensen et al., 2012) analyzed with a similar 2-DE method ( $\mathrm{pH}$ 4-7 IPG strip, $12 \% / 12.5 \%$ SDS-PAGE).

Table 3. Mass spectrometric identification of differentially expressed proteins in milk with abomasal infusion of ferrous lactate and direct addition of ferrous sulfate during treatments

\begin{tabular}{|c|c|c|c|c|c|c|}
\hline Spot ID $^{1}$ & Protein name & $\begin{array}{l}\text { Accession } \\
\text { no. }\end{array}$ & $\begin{array}{l}\text { Mascot } \\
\text { score }\end{array}$ & $\begin{array}{l}\text { Matched } \\
\text { peptides }\end{array}$ & $\begin{array}{l}\text { Protein } \mathrm{MW}^{2} \\
\quad(\mathrm{kDa})\end{array}$ & $\begin{array}{l}\text { Protein } \\
\mathrm{PI}^{3}\end{array}$ \\
\hline $\begin{array}{c}1,2,3,4,5,10,19,21,22,23,34,35,37,41 \\
42,43,44,45,52,55,59,60,67,68,69\end{array}$ & $\alpha_{S 1}$-Casein & gi $\mid 225632$ & 292 & 4 & 27.3 & 4.6 \\
\hline $11,12,13,14,15$ & Serum albumin & gi 472346475 & 118 & 2 & 66.4 & 5.6 \\
\hline 16 & Lactoferrin & gi| 85700158 & 341 & 6 & 78 & 8.7 \\
\hline 17 & Lactoperoxidase & gi 27806851 & 338 & 5 & 81 & 8.8 \\
\hline 25,51 & IgM heavy chain & gi| 108750 & 209 & 2 & 49 & 5.6 \\
\hline $27,28,29,30,31,32,33,62$ & $\kappa$-Casein & gi| 162811 & 238 & 5 & 21 & 6.3 \\
\hline 46 & $\alpha$-Lactalbumin & gi 68 & 212 & 4 & 17 & 4.8 \\
\hline
\end{tabular}

${ }^{1}$ Identified proteins using the National Center Biotechnology Information nonredundant amino acid sequence database (https://www.ncbi.nlm. nih.gov/refseq/).

${ }^{2}$ Molecular weight (theoretical).

${ }^{3}$ Isoelectric point (theoretical). 
Figure 1 (top row) illustrates the representative proteome of milk (from cow A) as illustrated with increasing concentrations of ferrous lactate infusion. Based on Wilcoxon test, milk protein spots with significant $(P<0.05)$ fold changes $(\geq 2$-fold $)$ in intensity during abomasal infusion of ferrous lactate were grouped into dotted (whey proteins) or lined (caseins) boxes in Figure 1. Compared with the control group $(0 \mathrm{mg} \mathrm{Fe} / \mathrm{L})$, spot $4\left(\alpha_{\mathrm{S}_{1}} \mathrm{CN}\right)$ and spot $47(\beta-\mathrm{CN})$ were significantly decreased in intensity in the low, medium, and high treatments. In addition, spots 34,36 , and $67(\beta-\mathrm{CN})$ and spot $5\left(\alpha_{S_{1}-} \mathrm{CN}\right)$ were consistently decreased $(P<$ $0.05)$ with increasing levels of abomasally infused ferrous lactate.

As shown in Figure 1, one protein could have several spots separated along the IPG strips, indicating that the additional spots (with different isoelectric points) originated from major milk proteins that underwent alterations such as proteolysis, posttranslational modification, and interaction or association with major milk proteins. For example, spots 34, 36, and 67 were low-molecular-weight degradation products of $\beta$-CN. Proteolysis may be induced by the activity of the principal indigenous milk protease plasmin or by other indigenous or exogenous proteases in milk (Chevalier et al., 2009).

The decreased expression of caseins found in this work might due to iron-induced oxidative stress. When iron exceeds the demand of dairy cattle, the concentration of reactive oxygen and nitrogen species $\left({ }^{\bullet} \mathrm{OH}, \mathrm{O}_{2}{ }^{\bullet-}\right.$, and $\mathrm{NO}^{\bullet}$ ) increases, which is known as oxidative stress (Puntarulo, 2005). Iron-induced oxidative stress is reported to influence the activity of hormones in living systems, such as the development of insulin resistance (Rains and Jain, 2011). Milk protein synthesis has a high requirement of energy, and one important way of generating greater dietary energy during milk protein synthesis is the increase of insulin secretion (Reynolds et al., 1994). Yield of milk protein shows a strong and positive relationship with the concentration of insulin in dairy cows (Winkelman and Overton, 2010). The interruption of insulin signal resulting from an oxidation environment will fail to activate signal transducer and activator of transcription 5 (STAT5)-E74-like factor 5 (ELF5), which is critical in controlling gene expression and translation during milk protein synthesis (Menzies et al., 2009, 2010), thus decreasing the yield of milk proteins.

Another consequence of oxidative stress is the accumulation of oxidized protein. When free iron is available, which is determined by the concentrations of iron-binding proteins (e.g., lactoferrin, transferrin) and iron-responsive factors (controlling the binding and release of iron from iron-binding proteins), derivatives of protein oxidation such as $\mathrm{H}_{2} \mathrm{O}_{2}$ can generate the even more toxic ${ }^{\circ} \mathrm{OH}$ by iron-catalyzed cleavage through the Fenton reaction (Berlett and Stadtman, 1997). It has been demonstrated that the primary oxidative damage to proteins is metal-catalyzed oxidation (Berlett and Stadtman, 1997; Stadtman and Berlett, 1998). To minimize the damage (protein aggregation and cross-linking) induced by protein oxidation, a series of antioxidant defenses mechanisms are activated within dairy cattle. Most oxidized proteins are degraded by proteolytic pathways to minimize protein aggregation and remove potentially toxic protein fragments (Berlett and Stadtman, 1997). We suggest that this might explain the proteolysis of $\beta$-CN fragments (spots 34 , 36,67 ) along with the increasing levels of abomasally infused ferrous lactate.

As expected, variations in milk proteome among the 4 individual farm cows were found in this work. Remarkably, whey proteins of different cows showed a large variation during abomasal infusion of ferrous lactate. Whey protein spots of interest were grouped by dashed boxes in Figure 1, and the grouped areas I and II were excised and compared within each individual farm cow under each abomasal infusion treatment (Figure 2 and Figure 3).

As shown in Figure 2, there were obvious decreases ( $\geq 2$-fold) in $\operatorname{IgG}_{1}$ heavy chain, IgM heavy chain, lactoperoxidase, and lactoferrin in the milk of cow A with low, medium, and high abomasal infusion treatments compared with control. Serum albumin proteins were decreased ( $\geq 2$-fold) by the low and medium abomasal infusion treatments in cow A. Serum albumin and lactoperoxidase in cow C illustrated a decrease ( $\geq 2$-fold) only with the low abomasal infusion treatment. However, all the immunoglobulins ( $\operatorname{IgG}_{1}$ heavy chain and IgM heavy chain) in cow $\mathrm{C}$ showed increased intensity $(\geq 2$-fold) with the medium and high abomasal infusion treatments. For cows B and D, all immunoglobulins were relatively stable during abomasal infusion treatments.

Immune proteins such as lactoperoxidase, lactoferrin, immunoglobulins, and serum albumin are expressed at a higher level in association with mastitis, which suggests their role in the innate nonspecific defense system (Madureira et al., 2007). In addition, increasing levels of lactoferrin were demonstrated as oxidative stress-related parameters due to its antioxidant activity based on Fe-binding ability (Thome et al., 1997). In this study, lactoperoxidase, lactoferrin, and immunoglobulins in cow $C$ illustrated a clear increase ( $\geq 2$-fold) associated with higher amounts of abomasal infused ferrous lactate. The increase of immune defense proteins might be the direct response to the iron-induced oxidative stress in cow $\mathrm{C}$. 

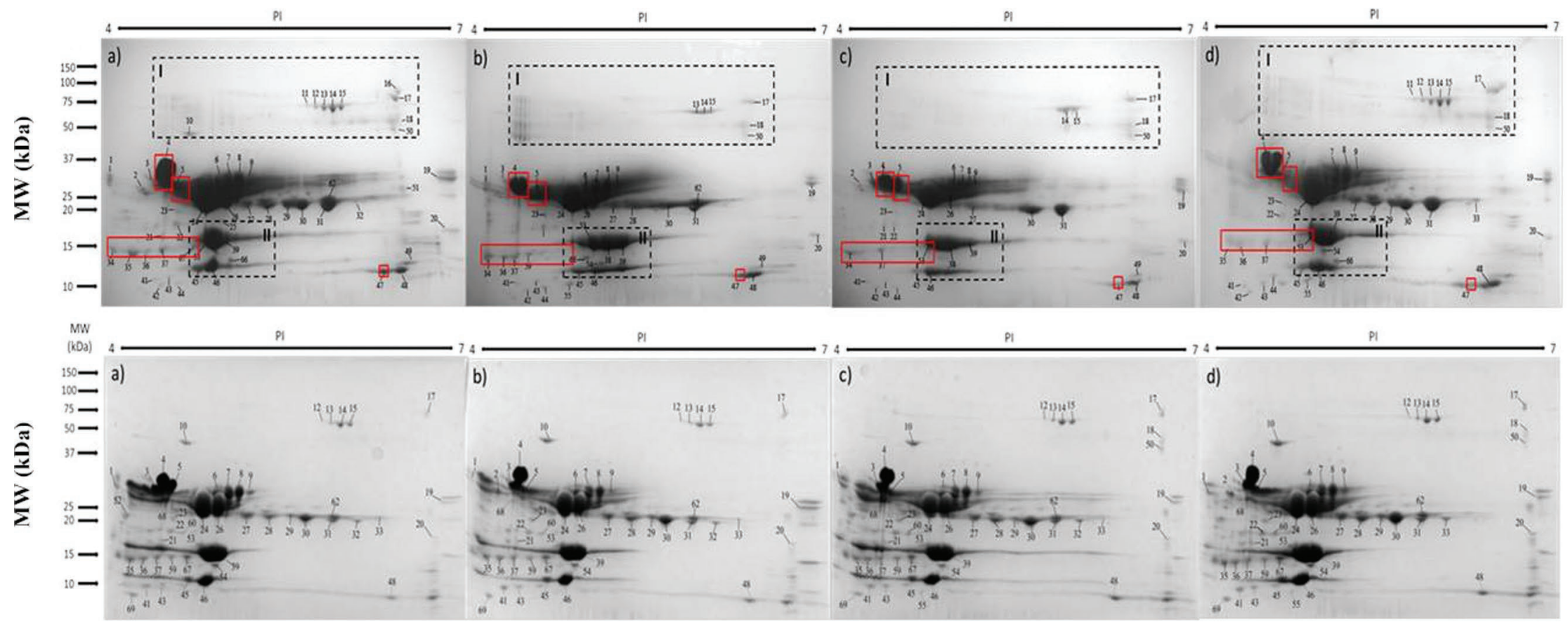

Figure 1. Protein composition of laboratory-pasteurized milk from a representative abomasal ferrous lactate infused cow (top row) and commercially retail milk with direct addition of ferrous sulfate (bottom row) during (a) control (0 mg of Fe/L), (b) low (2 mg of Fe/L), (c) medium (5 mg of Fe/L), and (d) high (12.5 mg of Fe/L) treatments. Each 2-dimensional electrophoresis gel ( $\mathrm{pH} 4-7$ ) was loaded with $200 \mu \mathrm{g}$ of protein and stained with Coomassie Blue. Solid boxes indicate affected casein proteins; dotted boxes identify regions of affected whey proteins. Color version available online. 

$0 \mathrm{mg} / \mathrm{L}$
$2 \mathrm{mg} / \mathrm{L}$
$5 \mathrm{mg} / \mathrm{L}$
$12.5 \mathrm{mg} / \mathrm{L}$

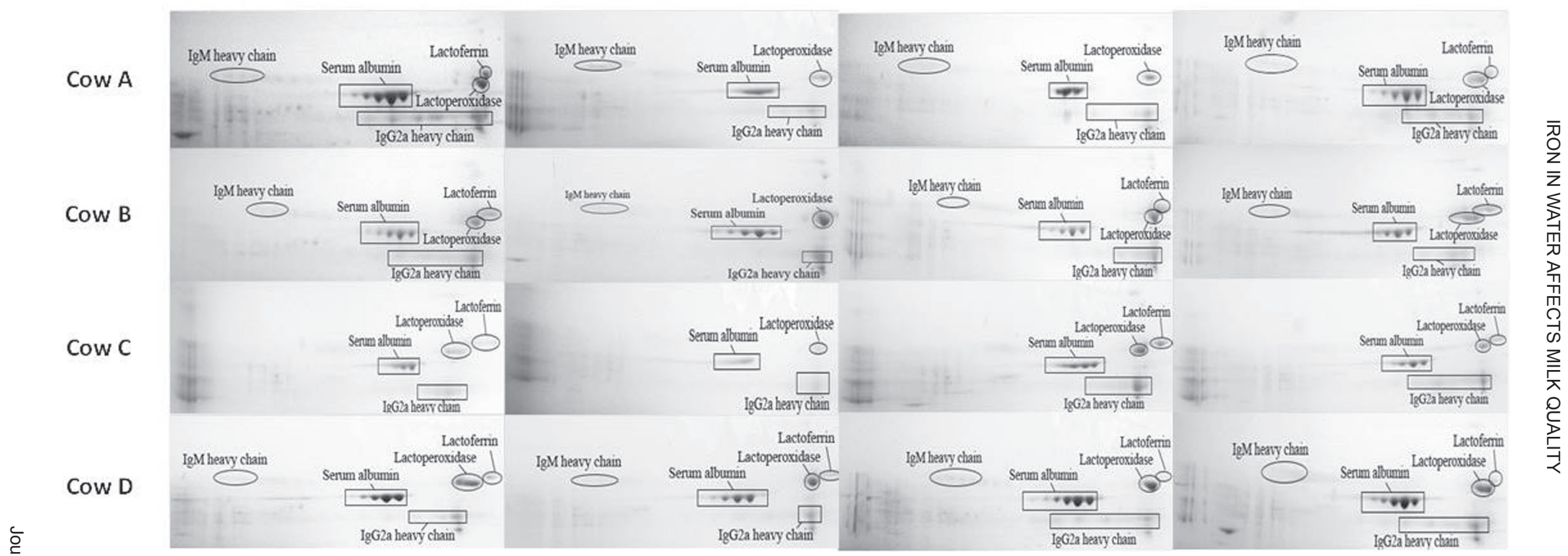

Figure 2. Area I (whey proteins; larger dotted box in Figure 1) from 4 individual farm cows with abomasal infusion of ferrous lactate during (a) control (0 mg of Fe/L), (b) o low $(2 \mathrm{mg}$ of Fe/L), (c) medium (5 mg of Fe/L), and (d) high (12.5 mg of Fe/L) treatment. Each 2-dimensional electrophoresis gel (pH 4-7) was loaded with $200 \mu \mathrm{g}$ of protein and . $\quad$ stained with Coomassie Blue. 
Cow A

$0 \mathrm{mg} / \mathrm{L}$

$2 \mathrm{mg} / \mathrm{L}$

$5 \mathrm{mg} / \mathrm{L}$

$12.5 \mathrm{mg} / \mathrm{L}$

Cow B

Cow C
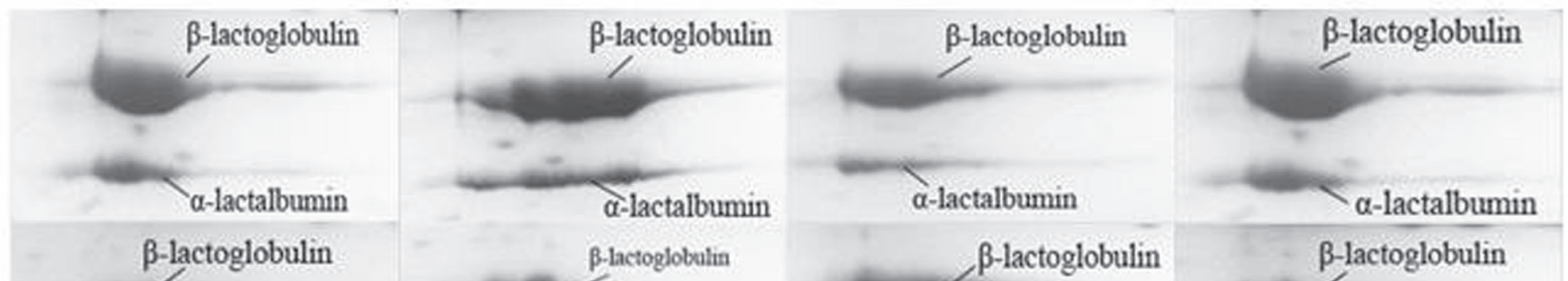

$\beta$-lactoglobulis
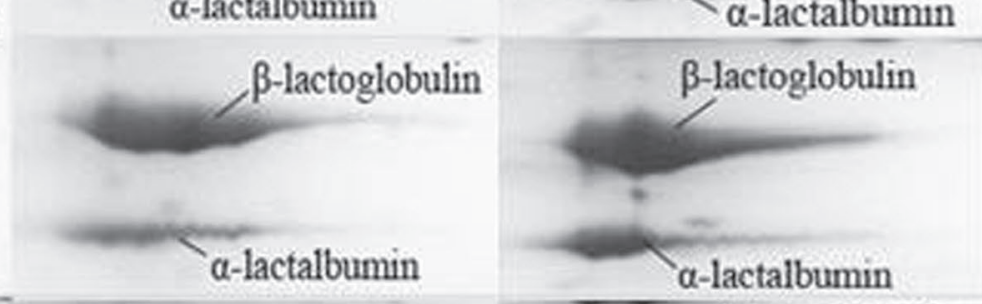

\section{Cow D}
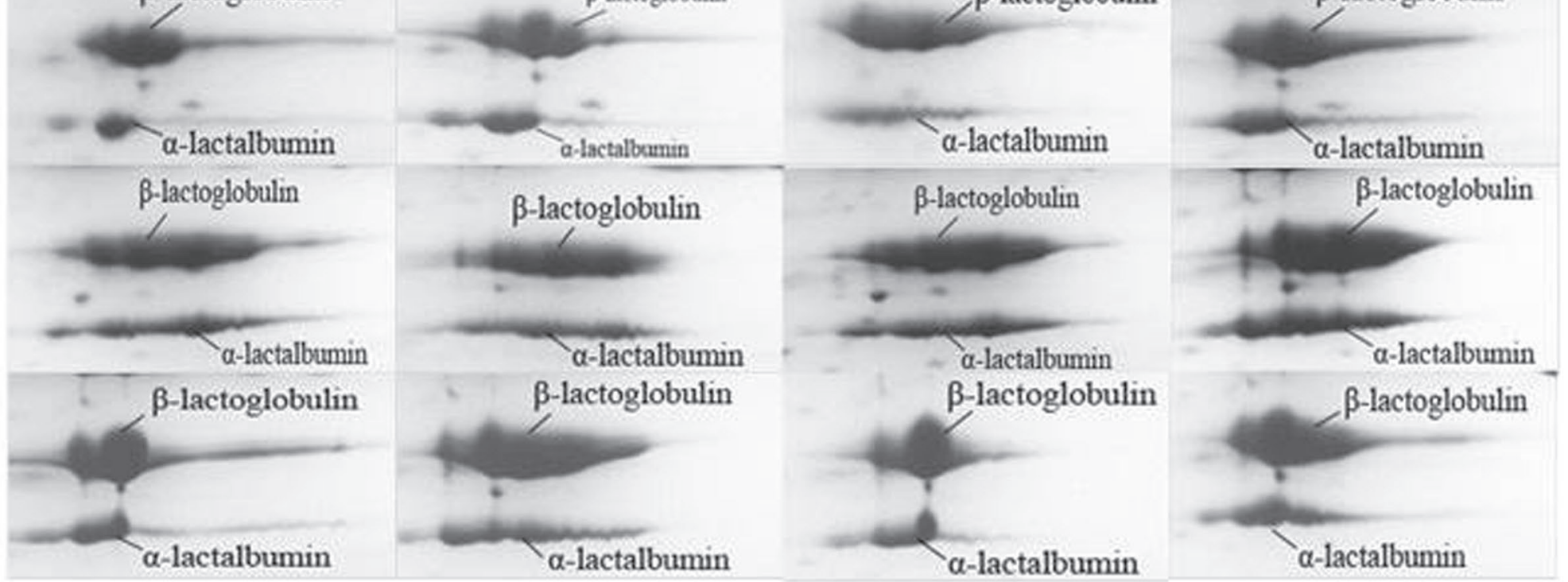

Figure 3. Area II (whey proteins; smaller dotted box in Figure 1) from 4 individual farm cows with abomasal infusion of ferrous lactate during (a) control (0 mg of Fe/L), (b) low $(2 \mathrm{mg}$ of Fe/L), (c) medium ( $5 \mathrm{mg}$ of $\mathrm{Fe} / \mathrm{L})$, and (d) high (12.5 mg of Fe/L) treatment. Each 2-dimensional electrophoresis gel (pH 4-7) was loaded with $200 \mu \mathrm{g}$ of protein and stained with Coomassie Blue. 
In contrast, immune defense proteins showed an overall decrease ( $\geq 2$-fold) in the low iron infusion treatment for cows $\mathrm{A}$ and $\mathrm{C}$ compared with the control. Dairy cows have a moderate but consistent increase in genes coding for lactoperoxidase and lactoferrin through lactation (Bionaz et al., 2012). The upregulated expression of these 2 typical immune proteins indicated an increase in the innate immune response of the mammary gland during lactation (Loor et al., 2011). Therefore, a constant increase in lactoferrin production may have functioned to bind ferrous ions in abomasally infused dairy cows, which work together with lactoperoxidase (antioxidant) to fight iron-induced oxidative stress in the cow. Consequently, the expression of lactoperoxidase and lactoferrin in the synthesized milk might be decreased for cows with greater susceptibility to oxidative stress, as these proteins are utilized for protection. It is possible that, due to the self-repairing system/ self-antioxidant defense of dairy cows, the immune system could be triggered and produce higher amounts of defense milk proteins in correspondence with increasing oxidative stress. The ability of a more robust selfrepairing system/self-antioxidant defense in dairy cows also might explain the relatively stable concentration of immune proteins in cows B and D during abomasal infusion of ferrous lactate.

As shown in Figure 3, posttranslational modifications of $\alpha-\mathrm{LA}$ and $\beta$-LG were found in cows $\mathrm{A}$ and $\mathrm{C}$ with the low abomasal infusion treatment, and in cow $\mathrm{B}$ with the medium abomasal infusion treatment. Cow $\mathrm{C}$ experienced a posttranslational modification of $\alpha$-LA and $\beta$-LG under all abomasal infusion treatments. It has been reported that some types of posttranslational modification are due to oxidative stress (Grimsrud et al., 2008). Although the mechanism of posttranslational modification of $\alpha-\mathrm{LA}$ and $\beta-\mathrm{LG}$ caused by oxidative stress is not well studied, posttranslational modifications are reported to affect the activity and function of most eukaryote proteins (Mann and Jensen, 2003). Therefore, posttranslational modification and degradation of whey proteins might reduce the nutritional value in bovine milk and related dairy products.

\section{Effect of Direct Addition of Ferrous Sulfate on Protein Composition of Commercial Retail Milk}

To compare with milk proteome induced by abomasal infusion of ferrous lactate, changes of protein composition in commercial retail milk caused by direct (in vitro) addition of ferrous sulfate were analyzed. Total protein concentration in the commercial retail milk was $3.51 \pm 0.09 \%$, which was within the normal range (2.97-3.74\%) reported by Lundén et al. (1997). Identi- fied protein spots are listed in Table 3 and marked on each 2-DE image with consistent spot ID numbers.

For milk with direct addition of ferrous sulfate, a large number of protein spots were found differentially expressed associated with the increasing concentrations of ferrous sulfate (Figure 1; bottom row). Compared with the control group, the low iron treatment induced a decrease ( $\geq 2$-fold) in $\alpha_{\mathrm{S} 1}$-CN (spots $1,2,3,5,52,59$ ), $\alpha_{\mathrm{S}_{2}} \mathrm{CN}$ precursor (spots $\left.6,8,9\right), \beta-\mathrm{CN}$ (spot 24$)$, and $\beta$-LG (spot 39$)$ but an increase $\left(\geq 2\right.$-fold) in $\alpha_{S 1}-\mathrm{CN}$ (spots 4,19$)$ and $\beta-\mathrm{CN}$ (spot 48 ). Medium iron treatment reduced the intensity ( $\geq 2$-fold) of $\alpha_{\mathrm{S} 1}$-CN (spots $3,5,37,43,52), \alpha_{S_{2}} \mathrm{CN}(\operatorname{spot} 8)$, and $\beta-\mathrm{CN}$ (spots 24 , $31)$ but enhanced $\left(\geq 2\right.$-fold) $\alpha_{S_{1}}-\mathrm{CN}($ spots 4,19$)$ and $\beta$-CN (spot 48). High iron treatment decreased $(\geq 2$ fold) expression of $\alpha_{\mathrm{S1}^{-}} \mathrm{CN}$ (spots $\left.2,3,5\right)$ and $\alpha_{\mathrm{S}_{2}} \mathrm{CN}$ precursor (spots 7,8$)$ and increased $(\geq 2$-fold) expression of $\alpha_{\mathrm{S} 1}-\mathrm{CN}(\operatorname{spots} 4,10,19,41), \beta-\mathrm{CN}(\operatorname{spot} 48)$, $\kappa-\mathrm{CN}$ (spots 28, 29, 30), and $\beta$-LG (spot 20).

Compared with whey proteins, a large number of casein spots were decreased $(\geq 2$-fold) in intensity in commercial retail milk with direct addition of ferrous sulfate. Degree of protein degradation in processed fluid milk varies with multiple factors, such as number of heat-stable proteinases (Dogan and Boor, 2003), storage time, and SCC in the raw milk (Barbano et al., 2006). Proteolysis may serve as the primary pathway for the large degree of protein degradation induced by the addition of ferrous ions. As the response to iron-induced oxidative stress, heat-stable proteolytic enzymes were considered the primary enzyme for protein hydrolysis in UHT-processed commercial retail milk (Fairbairn and Law, 1986; Grufferty and Fox, 1988). These proteinases can be native milk alkaline proteinases (e.g., plasmin; Grufferty and Fox, 1988) or extracellular bacterial proteinases produced by microorganisms (e.g., psychrotrophs) growing in raw milk before processing (Fairbairn and Law, 1986). For example, plasmin is able to rapidly cleave $\beta-\mathrm{CN}$ into the smaller $\beta-\mathrm{CN}$ and other polypeptide fragments, and milk proteins most susceptible to plasmin activity are $\beta-\mathrm{CN}, \alpha_{\mathrm{S}_{2}} \mathrm{CN}$, and $\alpha_{\mathrm{S} 1^{-}} \mathrm{CN}$ (Eigel et al., 1979; Bars and Gripon, 1989; McSweeney et al., 1993).

In addition, when reaching the optimum degree of oxidative damage of one protein, proteolytic activity is decreased along with the increase of oxidation level (Shanely et al., 2002). It was found that heavily oxidized proteins are extensively cross-linked and aggregated and unable to be degraded by proteinases (Pacifici et al., 1993; Giulivi et al., 1994). This statement was further demonstrated by our study; more protein spots were observed in proteolysis in the low iron treatment than in the high iron treatment. For example, spots 1 
and $59\left(\alpha_{\mathrm{S}^{-}} \mathrm{CN}\right)$, spots 6 and $9\left(\alpha_{\mathrm{S}^{-}} \mathrm{CN}\right.$ precursor $)$, and spot $39(\beta-\mathrm{LG})$ were only found degraded (decreased in intensity) in lower iron treatments.

Proteolysis of milk often results in bitter and astringent off-flavors (Harwalkar et al., 1993). Degradation of amino acids in proteolytic milk would further produce putrid flavors (Shipe et al., 1978). The production of off-flavor in proteolytic milk might explain the sensory differences observed in processed milk in our previous study (Mann et al., 2013). Besides, proteolysis of milk proteins reduces flavor and nutritional value in related dairy products, such as infant formula, dietetics, and other functional foods (de Wit, 1998). Because concentrations of $\alpha_{\mathrm{S}^{-}}, \beta-$, and $\kappa-\mathrm{CN}, \beta-\mathrm{LG}$, and the proportion of $\kappa-\mathrm{CN}$ to total casein were found to be significant for the cheese yield (Wedholm et al., 2006), the degradation of $\alpha_{\mathrm{S1}^{-}}, \beta-, \kappa_{-} \mathrm{CN}$ and $\beta-\mathrm{LG}$ found in milk with direct addition of ferrous lactate might affect the quality of cheese if such milk were used in cheese making. In addition, casein hydrates in proteolysis milk were degraded to either lower molecular weight peptides or protein fragments with altered isoelectric points, which we speculated further reduced cheese yield based on the isoelectric point value $(\sim \mathrm{pH} 4.6)$ of casein.

\section{Effect of Abomasal Infusion of Ferrous Lactate and Direct Addition of Ferrous Sulfate on Milk Oxidative Stability}

Oxidative stability of milk with direct addition of ferrous lactate was evaluated by the TBARS assay, which estimates volatile aldehydes. Oxidation level is positively related to TBARS value. As shown in Table 4 , we detected no significant difference $(P>0.05)$ in aldehyde concentration between control $(0.26 \pm 0.02$ $\mathrm{mg} / \mathrm{kg})$ and the low iron treatment $(0.27 \pm 0.01 \mathrm{mg} /$ $\mathrm{kg}$ ) in commercially processed milk after $1 \mathrm{~d}$ of storage (light-protected, $4^{\circ} \mathrm{C}$ ). However, the TBARS value was increased $(P<0.05)$ in the medium iron treatment $(0.31 \pm 0.01 \mathrm{mg} / \mathrm{kg})$ and increased further $(P$ $<0.05)$ in the high iron treatment $(0.40 \pm 0.02 \mathrm{mg} /$ $\mathrm{kg}$ ). After $8 \mathrm{~d}$ of storage, the MDA concentration of milk in all treatments was higher than that on the first day of ferrous sulfate addition. The medium and high iron treatments still led to a significantly higher $(P<$ 0.05 ) oxidation level compared with milk without $\mathrm{Fe}$ addition, but we observed no significant differences in TBARS values between the low and medium iron treatments. This result indicated that oxidation occurred in iron-added milk during storage at $4^{\circ} \mathrm{C}$, even with light protection.

Oxidation of commercial retail milk in this study was primarily caused by the addition of ferrous sulfate, because all of the milk samples were covered by foil for light protection during $8 \mathrm{~d}$ of storage. Oxidation can detrimentally affect the nutritional value and flavor of milk. Because total aldehydes, including MDA, are secondary oxidative products from milk oxidation and primarily contribute to oxidation-induced off-flavors (Alvarez, 2009), a much more reliable method to identify oxidized milk was sensory evaluation. In our previous work (Mann et al., 2013), it was suggested that $3 \mathrm{mg} / \mathrm{L}$ ferrous sulfate solution resulted in slightly oxidized milk that showed sensory differences compared with fresh milk. This result suggested that even slightly oxidized milk produced off-flavor in milk and could be distinguished from nonoxidized milk by sensory analysis.

In this study, oxidation in milk caused by ferrous ions showed an increase after $8 \mathrm{~d}$ of storage, demonstrating that ferrous ions present in fluid milk early in shelf life could contribute to decreasing quality and flavor during storage. Although metal-binding proteins in milk, including lactoferrin, casein, caseinophosphopeptides (CPP) and casein hydrolysates, can work as metal chelators and effectively bind with iron (Bouhallab and Bouglé, 2004), their amounts in milk may be too low to bind with all the added ferrous ions available under the conditions of our treatments. Most chelators take effect as prooxidants once their concentrations are lower than that of iron (Mahoney and Graf, 1986; Díaz and Decker, 2004).

Oxidative stability of milk from abomasal ironinfused cows was analyzed in our previous work (Mann et al., 2013). Overall, TBARS values of milk were not significantly changed with the increase in iron infusion, although milk from 3 of 4 cows showed a general increase in aldehydes as estimated by TBARS. After storage for $1 \mathrm{wk}$, TBARS value in milk still did not show any significant changes. Although TBARS analyses did not show any oxidation based on estimate of aldehydes, sensory tests indicated that oxidative off-flavors oc-

Table 4. Thiobarbituric acid reactive substance (TBARS) values, expressed as malondialdehyde concentration $(\mathrm{mg} / \mathrm{kg}$; mean $\pm \mathrm{SE}$ ), as an indication of oxidation in commercial retail milk with direct addition of ferrous sulfate

\begin{tabular}{lccc}
\hline Treatment $^{1}$ & $\begin{array}{c}\text { Fresh } \\
\text { milk }\end{array}$ & $\begin{array}{c}\text { Day 1 } \\
\text { of storage }\end{array}$ & $\begin{array}{c}\text { Day } 8 \\
\text { of storage }\end{array}$ \\
\hline Control & $0.22 \pm 0.02$ & $0.26 \pm 0.02^{\mathrm{a}}$ & $0.27 \pm 0.02^{\mathrm{a}}$ \\
Low & & $0.27 \pm 0.01^{\mathrm{a}}$ & $0.29 \pm 0.01^{\mathrm{ab}}$ \\
Medium & & $0.31 \pm 0.01^{\mathrm{b}}$ & $0.33 \pm 0.02^{\mathrm{b}}$ \\
High & & $0.40 \pm 0.02^{\mathrm{c}}$ & $0.44 \pm 0.01^{\mathrm{c}}$ \\
\hline
\end{tabular}

$\overline{{ }^{a-c} \text { Means within each column with different superscripts are different }}$ $(P<0.05)$.

${ }^{1}$ Concentrations of iron in milk with direct iron addition were $0,2,5$, and $12.5 \mathrm{mg}$ of $\mathrm{Fe} / \mathrm{L}$ for control, low, medium, and high treatments, respectively. 
curred in milk with abomasal infusion of ferrous lactate (Mann et al., 2013).

\section{Effect of Abomasal Infusion of Ferrous Lactate and Direct Addition of Ferrous Sulfate on Mineral Contents in Milk}

Minerals that were listed in the standard reference for milk in the National Nutrient Database (USDA, 2016; Appendix Table A1) were quantified by inductively coupled plasma-MS in this work, including sodium, magnesium, calcium, potassium, copper, iron, zinc, and inorganic phosphorus. As expected, iron concentration in milk significantly increased $(P<0.05)$ with increasing addition of ferrous sulfate (data not shown). However, none of the other minerals showed any obvious changes during this process, which indicated that other minerals in milk did not interact with the increasing iron. Because Fe concentration in regular processed milk ranges from 0.17 to $1.45 \mathrm{mg} / \mathrm{L}$ (Murthy et al., 1972), iron addition in the low treatment (2 mg of $\mathrm{Fe} / \mathrm{L}$ ) resulted in excessive Fe compared with that of regular commercial milk.

Mineral contents in milk with abomasal infusion of ferrous lactate were reported in our previous work (Mann et al., 2013). Concentrations of $\mathrm{Fe}, \mathrm{Cu}, \mathrm{P}$, and $\mathrm{Ca}$ in milk did not present significant differences $(P>$ $0.05)$ with the increase of iron intake $(935 \pm 26 \mathrm{mg} /$ $\mathrm{kg} \mathrm{Ca}, 0.040 \pm 0.001 \mathrm{mg} / \mathrm{kg} \mathrm{Cu}, 0.220 \pm 0.010 \mathrm{mg} /$ $\mathrm{kg} \mathrm{Fe}, 847 \pm 27 \mathrm{mg} / \mathrm{kg} \mathrm{P}$ ). The low variation in these minerals may be due to the iron-binding proteins that chelated extra iron or the self-repairing system of cows that inhibited oxidation. The infusion was much shorter (14 vs. $45 \mathrm{~d}$ for iron treatment) and at a lower level of Fe supplementation (705 mg vs. 1,000 $\mathrm{mg}$ of $\mathrm{Fe} / \mathrm{kg}$ of DM) than that of Standish et al. (1971). The overall $\mathrm{Fe}$ and $\mathrm{Ca}$ contents of milk with abomasal infusion of ferrous lactate were lower than those of commercial retail milk. This can be explained by the differences due to different breed of cow or the influence of high iron intake on cows. The Ca:P ratio was around 5:3 in milk with direct addition of ferrous sulfate in this work and around 3:3 in milk with abomasal infusion of ferrous sulfate (Mann et al., 2013). The Ca:P molar ratio $(\sim 4: 3)$ is one of the most important factors in cheese making, and calcium phosphate plays an integral part in curd formation and stabilization (Mekmene et al., 2009). A high or low Ca:P ratio in milk might decrease the quality and yield of final cheese products.

\section{CONCLUSIONS}

Both abomasal infusion of ferrous lactate and direct addition of ferrous sulfate as low as $2 \mathrm{mg}$ of Fe/L influ- ence the milk proteome. Abomasal infusion of ferrous lactate affected both caseins and whey proteins in milk of lactating dairy cows, although the effects varied among individual farm cows with different concentrations of infused iron. Direct addition of ferrous sulfate to the commercial milk mainly affected caseins. Abomasal infusion of ferrous lactate did not significantly affect the oxidation state in milk of individual farm cows. In contrast, iron-induced oxidation occurred in milk with direct addition of ferrous sulfate during storage at $4^{\circ} \mathrm{C}$. Neither abomasal infusion nor direct addition of iron significantly affected the mineral composition of milk, except for increasing levels of Fe. A small amount of iron contamination in bovine drinking water or milk processing plant can cause changes in milk protein composition and oxidation in the final milk product, which decreases the quality, sensory profile, and nutritional value of milk and related dairy products.

\section{ACKNOWLEDGMENTS}

This project was funded, in part, by the Virginia Tech College of Agriculture and Life Sciences Pratt Endowment, Virginia Agricultural Experiment Station (Blacksburg), the Hatch Program of the National Institute of Food and Agriculture, US Department of Agriculture (Washington, DC), and the VT Water INTERface Interdisciplinary Graduate Education Program. The authors acknowledge Xin Feng (Department of Dairy Science, Virginia Tech, Blacksburg) for her design and management of the preharvest study, and Georgianna Mann (Department of Food Science and Technology, Virginia Tech, Blacksburg) for her previous work on processing cow milk from abomasal iron infusion and sensory analysis. The authors also thank Dennis Dean and Valerie Cash (Fralin Life Science Institute, Virginia Tech, Blacksburg) for programmatic support.

\section{REFERENCES}

Adlerova, L., A. Bartoskova, and M. Faldyna. 2008. Lactoferrin: A review. Vet. Med. (Praha) 53:457-468.

Alonso-Fauste, I., M. Andrés, M. Iturralde, F. Lampreave, J. Gallart, and M. Álava. 2012. Proteomic characterization by 2-DE in bovine serum and whey from healthy and mastitis affected farm animals. J. Proteomics 75:3015-3030.

Alvarez, V. B. 2009. Fluid milk and cream products. Chapter 5 in The Sensory Evaluation of Dairy Products. 2nd ed. S. Clark, M. Costello, M. Drake, and F. Bodyfelt, ed. Springer, New York, NY.

Bansal, B. K., J. Hamann, N. T. Grabowski, and K. B. Singh. 2005. Variation in the composition of selected milk fraction samples from healthy and mastitis quarters, and its significance for mastitis diagnosis. J. Dairy Res. 72:144-152.

Barbano, D. M., Y. Ma, and M. V. Santos. 2006. Influence of raw milk quality on fluid milk shelf life. J. Dairy Sci. 89(E. Suppl.):E15-E19.

Berlett, B. S., and E. R. Stadtman. 1997. Protein oxidation in aging, disease, and oxidative stress. J. Biol. Chem. 272:20313-20316. 
Bionaz, M., W. Hurley, and J. Loor. 2012. Milk protein synthesis in the lactating mammary gland: Insights from transcriptomics analyses. InTech Open Access Publisher, Rijeka, Croatia.

Bouhallab, S., and D. Bouglé. 2004. Biopeptides of milk: Caseinophosphopeptides and mineral bioavailability. Reprod. Nutr. Dev. 44:493-498.

Bruckmaier, R. M., D. Weiss, M. Wiedemann, S. Schmitz, and G. Wendl. 2004. Changes of physicochemical indicators during mastitis and the effects of milk ejection on their sensitivity. J. Dairy Res. 71:316-321.

Bullen, J. J., H. J. Rogers, and E. Griffiths. 1978. Role of iron in bacterial infection. Curr. Top. Microbiol. Immunol. 80:1-35.

Chevalier, F., D. Centeno, V. Rofidal, M. Tauzin, N. Sommerer, and M. Rossignol. 2006. Differential capacity of visible stains and fluorescent dyes for large-scale investigation of proteomes by MALDITOF MS. J. Proteome Res. 5:512-520.

Chevalier, F., C. Hirtz, N. Sommerer, and A. L. Kelly. 2009. Use of reducing/nonreducing two- dimensional electrophoresis for the study of disulfide-mediated interactions between proteins in raw and heated bovine milk. J. Agric. Food Chem. 57:5948-5955.

Clare, D. A., C. L. Catignani, and H. E. Swaisgood. 2003. Biodefense properties of milk, the role of antimicrobial proteins and peptides. Curr. Pharm. Des. 9:1239-1255.

de Wit, J. N. 1998. Nutritional and functional characteristics of whey proteins in food products. J. Dairy Sci. 81:597-608.

Díaz, M., and E. A. Decker. 2004. Antioxidant mechanisms of caseinophosphopeptides and casein hydrolysates and their application in ground beef. J. Agric. Food Chem. 52:8208-8213.

Dogan, B., and K. Boor. 2003. Genetic diversity and spoilage potentials among Pseudomonas spp. Isolated from fluid milk products and dairy processing plants. Appl. Environ. Microbiol. 69:130-138.

Eigel, W. N., C. J. Hofmann, B. A. Chibber, J. M. Tomich, T. W Keenan, and E. T. Mertz. 1979. Plasmin-mediated proteolysis of casein in bovine milk. Proc. Natl. Acad. Sci. USA 76:2244-2248.

Fairbairn, D. J., and B. A. Law. 1986. Proteinases of psychrotrophic bacteria: Their production, properties, effects and control. J. Dairy Res. 53:139-177.

Feng, X., K. F. Knowlton, A. D. Dietrich, and S. Duncan. 2013. Effect of abomasal ferrous lactate infusion on phosphorus absorption in lactating dairy cows. J. Dairy Sci. 96:4586-4591.

Ganjam, L. S., W. H. Thornton, R. T. Marshall, and R. S. MacDonald. 1997. Antiproliferative effects of yoghurt fractions obtained by membrane dialysis on cultured mammalian intestinal cells. J. Dairy Sci. 80:2325-2329.

Gill, H. S., and M. L. Cross. 2000. Anticancer properties of bovine milk. Br. J. Nutr. 84:S161-S165.

Giulivi, C., R. E. Pacifici, and K. J. A. Davies. 1994. Exposure of hydrophobic moieties promotes the selective degradation of hydrogen peroxide-modified hemoglobin by the multicatalytic proteinase complex, proteasome. Arch. Biochem. Biophys. 311:329-341.

Grimsrud, P. A., H. Xie, T. J. Griffin, and D. A. Bernlohr. 2008. Oxidative stress and covalent modification of protein with bioactive aldehydes. J. Biol. Chem. 283:21837-21841.

Gröhn, Y. T., D. J. Wilson, R. N. González, J. A. Hertl, H. Schulte, G. Bennett, and Y. H. Schukken. 2004. Effect of pathogen-specific clinical mastitis on milk yield in dairy cows. J. Dairy Sci. $87: 3358-3374$

Grufferty, M. B., and P. F. Fox. 1988. Review article: Milk alkaline proteinase. J. Dairy Res. 55:609-630.

Hansen, S. L., M. S. Ashwell, A. J. Moeser, R. S. Fry, M. D. Knutson, and J. W. Spears. 2010. High dietary iron reduces transporters involved in iron and manganese metabolism and increases intestinal permeability in calves. J. Dairy Sci. 93:656-665.

Harwalkar, V. R., H. Cholette, R. C. McKellar, and D. B. Emmons. 1993. Relation between proteolysis and astringent off-flavor in milk. J. Dairy Sci. 76:2521-2527.

Haug, A., A. T. Hostmark, and O. M. Harstad. 2007. Bovine milk in human nutrition-A review. Lipids Health Dis. 6:25.

Jensen, H. B., J. W. Holland, N. A. Poulsen, and L. B. Larsen. 2012. Milk protein genetic variants and isoforms identified in bovine milk representing extremes in coagulation properties. J. Dairy Sci 95:2891-2903.

Le Bars, D., and J. C. Gripon. 1989. Specificity of plasmin towards bovine $\alpha_{\mathrm{s} 2}$-casein. J. Dairy Res. 56:817-821.

Levieux, D., and A. Ollier. 1999. Bovine immunoglobulin G, $\beta$-lactoglobulin, $\alpha$-lactalbumin and serum albumin in colostrum and milk during the early post partum period. J. Dairy Res. $66: 421-430$.

Linn, J. 2008. Impact of minerals in water on dairy cows. Dairy Star. Accessed Jan. 23, 2016. http://www1.extension.umn.edu/ agriculture/dairy/feed-and-nutrition/impact-of-minerals-inwater/.

Loimaranta, V., M. Lain, E. Soèderling, E. Vasara, S. Rokka, P. Marnila, H. Korhonen, O. Tossavainen, and J. Tenovuo. 1999. Effects of bovine immune and non-immune whey preparations on the composition and $\mathrm{pH}$ response of human dental plaque. Eur. J. Oral Sci. 107:244-250

Loor, J. J., K. M. Moyes, and M. Bionaz. 2011. Functional adaptations of the transcriptome to mastitis-causing pathogens: The mammary gland and beyond. J. Mammary Gland Biol. Neoplasia 16:305-322.

Lundén, A., M. Nilsson, and L. Janson. 1997. Marked effect of $\beta$-lactoglobulin polymorphism on the ratio of casein to total protein in milk. J. Dairy Sci. 80:2996-3005.

Madureira, A. R., C. I. Pereira, A. M. P. Gomes, M. E. Pintado, and F. X. Malcta. 2007. Bovine whey proteins-overview on their main biological properties. Food Res. Int. 40:1197-1211.

Mahoney, J. R., and E. Graf. 1986. Role of alpha-tocopherol, ascorbic acid, citric acid and EDTA as oxidants in model systems. J. Food Sci. 51:1293-1296.

Mann, G. R., S. E. Duncan, K. F. Knowlton, A. D. Dietrich, and S. F. O'Keefe. 2013. Effects of mineral content of bovine drinking water: Does iron content affect milk quality? J. Dairy Sci. 96:7478-7489.

Mann, M., and O. N. Jensen. 2003. Proteomic analysis of post-translational modifications. Nat. Biotechnol. 21:255-261.

McSweeney, P. L., N. F. Olson, P. F. Fox, A. Hearly, and P. Hjrup. 1993. Proteolytic specificity of plasmin on bovine $\alpha_{\mathrm{s} 1}$-casein. Food Biotechnol. 7:143-158

Mekmene, O., S. Quillard, T. Rouillon, J. M. Bouler, M. Piot, and F. Gaucheron. 2009. Effect of $\mathrm{pH}$ and $\mathrm{Ca} / \mathrm{P}$ molar ratio on the quantity and crystalline structure of calcium phosphates obtained from aqueous solutions. Dairy Sci. Technol. 89:301-316.

Menegário, A. A., A. P. Packer, and M. F. Giné. 2001. Determination of $\mathrm{Ba}, \mathrm{Cd}, \mathrm{Cu}, \mathrm{Pb}$ and $\mathrm{Zn}$ in saliva by isotope dilution direct injection inductively coupled plasma mass spectrometry. Analyst 126:1363-1366.

Menzies, K. K., H. J. Lee, C. Lefevre, C. J. Ormandy, K. L. Macmillan, and K. R. Nicholas. 2010. Insulin, a key regulator of hormone responsive milk protein synthesis during lactogenesis in murine mammary explants. Funct. Integr. Genomics 10:87-95.

Menzies, K. K., C. Lefevre, K. L. Macmillan, and K. R. Nicholas. 2009. Insulin regulates milk protein synthesis at multiple levels in the bovine mammary gland. Funct. Integr. Genomics 9:197-217.

Micke, P., K. M. Beeh, and R. Buhl. 2002. Effects of long-term supplementation with whey proteins on plasma GSH levels of HIV infected patients. Eur. J. Nutr. 41:12-18.

Murthy, G. K., U. S. Rhea, and J. T. Peeler. 1972. Copper, iron, manganese, strontium, and zinc content of market milk. J. Dairy Sci. $55: 1666-1674$

Oona, M., T. Raego, H. I. Maaroos, M. Mikelsaar, K. Loivukene, S. Salminen, and H. Korhonen. 1997. Helicobacter pylori in children with abdominal complaints: Has immune bovine colostrum some influence on gastritis? Bacteriol. Abstr. B 6:49-57.

Pacifici, R. E., V. Kono, and K. J. A. Davies. 1993. Hydrophobicity as the signal for selective degradation of hydroxyl radical-modified hemoglobin by the multicatalytic proteinase complex, proteasome. J. Biol. Chem. 268:15405-15411.

Puntarulo, S. 2005. Iron, oxidative stress and human health. Mol. Aspects Med. 26:299-312.

Rains, J. L., and S. K. Jain. 2011. Oxidative stress, insulin signaling, and diabetes. Free Radic. Biol. Med. 50:567-575. 
Reynolds, C. K., D. L. Harmon, and M. J. Cecava. 1994. Absorption and delivery of nutrients for milk protein synthesis by portaldrained viscera. J. Dairy Sci. 77:2787-2808.

Senda, A., K. Fukuda, T. Ishii, and T. Urashima. 2011. Changes in the bovine whey proteome during the early lactation period. Anim. Sci. J. 82:698-706.

Shanely, R. A., M. S. Zergeroglu, S. L. Lennon, T. Sugiura, T. Yimlamai, D. Enns, A. Belcastro, and S. K. Powers. 2002. Mechanical ventilation-induced diaphragmatic atrophy is associated with oxidative injury and increased proteolytic activity. Am. J. Respir. Crit. Care Med. 166:1369-1374.

Shipe, W. F., R. Bassette, D. D. Deane, W. L. Dunkley, and E. G. Hammond. 1978. Off flavors of milk: nomenclature, standards, and bibliography. J. Dairy Sci. 61:855-869.

Stadtman, E. R., and B. S. Berlett. 1998. Reactive oxygen-mediated protein oxidation in aging and disease. Drug Metab. Rev. 30:225243.

Standish, J. F., C. B. Ammerman, A. Z. Palmer, and C. F. Simpson. 1971. Influence of dietary iron and phosphorus on performance, tissue mineral composition and mineral absorption in steers. J. Anim. Sci. 33:171-178.

Swaisgood, H. E. 1995. Protein and amino acid composition of bovine milk. Pages 464-468 in Handbook of Milk Composition. R. G. Jensen, ed. Academic Press, Toronto, ON, Canada.

Thome, J., W. Gsell, M. Rösier, J. Komhuber, L. Frolich, E. Hashimoto, B. Zielke, G. A. Wiesbeck, and P. Riedcrer. 1997. Oxidative- stress associated parameters (lactoferrin, superoxide dismutases) in serum of patients with Alzheimer's disease. Life Sci. 60:13-19.

USDA. 2016. Basic Report: 01076, Milk substitutes, fluid, with lauric acid oil. USDA Agricultural Research Service. National Nutrient Database for Standard Reference Release 28. Accessed Jan. 21, 2016. http://ndb.nal.usda.gov/ndb/foods/show/69.

USEPA (US Environmental Protection Agency). 2015. Edition of the Drinking Water Standards and Health Advisories. 2015. Office of Water, US EPA, Washington, DC.

Watanabe, M., M. Asatsuma, A. Ikui, M. Ikeda, Y. Yamada, S. Nomura, and A. Igarashi. 2005. Measurements of several metallic elements and matrix metalloproteinases (MMPs) in saliva from patients with taste disorder. Chem. Senses 30:121-125.

Wedholm, A., L. B. Larsen, H. Lindmark-Mansson, A. H. Karlsson, and A. Andrén. 2006. Effect of protein composition on the cheesemaking properties of milk from individual dairy cows. J. Dairy Sci. 89:3296-3305.

Winkelman, L. A., and T. R. Overton. 2010. Is there opportunity to boost milk protein production? Pages 123-132 in Proc. Cornell Nutrition Conference for Feed Manufacturers, East Syracuse, NY. Cornell University, Ithaca, NY.

Yamada, M., K. Murakami, J. C. Wallingford, and Y. Yuki. 2002. Identification of low-abundance proteins of bovine colostral and mature milk using two-dimensional electrophoresis followed by microsequencing and mass spectrometry. Electrophoresis 23:1153-1160.

\section{APPENDIX}

Table A1. Mineral content $(\mathrm{mg} / \mathrm{kg} ;$ mean $\pm \mathrm{SE})$ in commercial retail milk with direct addition of ferrous lactate ${ }^{1}$

\begin{tabular}{|c|c|c|c|c|c|c|c|}
\hline Treatment $^{2}$ & \multicolumn{7}{|c|}{ Mineral content $(\mathrm{mg} / \mathrm{kg})$} \\
\hline Control & $118.8 \pm 4.2^{\mathrm{a}}$ & $781.5 \pm 26.8^{\mathrm{a}}$ & $422.1 \pm 10.9^{\mathrm{a}}$ & $1,701.5 \pm 55.0^{\mathrm{a}}$ & $1,250.4 \pm 35.4^{\mathrm{a}}$ & $0.485 \pm 0.05^{\mathrm{a}}$ & $4.43 \pm 0.20^{\mathrm{a}}$ \\
\hline Medium & $118.7 \pm 1.0^{\mathrm{a}}$ & $749.3 \pm 33.5^{\mathrm{a}}$ & $421.3 \pm 3.9^{\mathrm{a}}$ & $1,683.9 \pm 12.0^{\mathrm{a}}$ & $1,256.0 \pm 10.6^{\mathrm{a}}$ & $4.58 \pm 0.12^{\mathrm{c}}$ & $4.21 \pm 0.13^{\mathrm{a}}$ \\
\hline High & $116.0 \pm 1.3^{\mathrm{a}}$ & $740.7 \pm 9.0^{\mathrm{a}}$ & $412.9 \pm 5.9^{\mathrm{a}}$ & $1,651.7 \pm 33.0^{\mathrm{a}}$ & $1,233.4 \pm 28.9^{\mathrm{a}}$ & $10.3 \pm 0.34^{\mathrm{d}}$ & $4.52 \pm 0.44^{\mathrm{a}}$ \\
\hline $\begin{array}{l}\text { USDA reported } \\
\text { value }^{3}\end{array}$ & 60.5 & 739.8 & 779.7 & $1,140.4$ & 330.0 & 3.9 & 11.8 \\
\hline
\end{tabular}

\footnotetext{
${ }^{\mathrm{a}-\mathrm{d}}$ In each column, different superscripts indicate significant differences $(P<0.05)$ among different iron treatments.

${ }^{1}$ Mineral contents of milk samples were analyzed by inductively coupled plasma spectroscopy following a nitric acid digestion.

${ }^{2}$ Concentrations of iron in milk with direct iron addition were $0,2,5$, and 12.5 of $\mathrm{Fe} / \mathrm{L}$ for control, low, medium, and high treatments, respectively.

${ }^{3}$ USDA-reported values are from http://ndb.nal.usda.gov/ndb/foods/show/69 (USDA, 2016).
} 